УДК 342.4

Ю. Констанкевич,

аспірант кафедри конституційного права

Національного університету «Одеська юридична академія»

\title{
КОНТИНУЇТЕТ ТРАДИЦІї МОРАЛЬНО-ЕТИЧНИХ СТАНДАРТІВ ПУБЛІЧНОї ВЛАДИ В ІСТОРІї УКРАЇНСЬКОЇ КОНСТИТУЦІї
}

Розвиток та еволюціонування конституційних явищ нерозривно пов'язані з тяглістю конституційної традиції, на основі якої функціонує конституційна система. Цінності й принципи, які становлять основу конституції, можуть грунтуватися, наприклад, на європейській чи американській моделях конституційного порядку, однак конституційна ідентичність кожної окремої держави, зокрема України, має право на вміщення свої характерних положень щодо функціонування влади чи механізму захисту прав людини. Норми чинної Конституції України спираються на багатовікову історію українського державотворення, частиною якої є прийняття або складання проектів конституцій Української держави. Принцип доброчесності владних представників, який можна прослідкувати в Конституції України, є поряд з інституційним механізмом і професійною компетентністю, одним із важливих аспектів діяльності органів публічної влади. Отже, поставлено завдання проаналізувати історичні конституційні акти 3 метою встановлення наявності чи відсутності континуїтету традиції морально-етичних стандартів влади в українській конституції.

Дослідження спирається як на офіційно прийняті законодавчі акти й проекти конституцій Української держави, починаючи від П. Орлика, надалі простежуючи продовження конституційної традиції в працях М. Костомарова, Г. Андрузького та конституційних актах XX сторіччя. Велику кількість сучасних конституційних проблем можна вирішити і спираючись на методологію історичного абстрагування, проте за наявності конституційної традиції доброчесності влади в широкому сенсі цього терміна (moral integrity) цей аспект потрібно враховувати як елемент багаторічного формування конституційної свідомості, що є чинником дії конституційної системи.

«Конституиіi Пилипа Орлика». Договори й постановлення прав і вольностей військових між Ясновельможним Його Милості паном Пилипом Орликом, новообраним гетьманом Війська Запорізького, і між генеральними особами, полковниками й тим же Військом Запорізьким (далі - Конституція 1710 р.), сьогодні більш відомі під назвою «Конституція Пилипа Орлика», затверджені 5 квітня 1710 р. Для визначення конституційної традиції та ідентичності конституційної системи в Україні вищезазначений документ відіграє значно важливу роль, позаяк основи правової думки, закладені в цих (як їх по-іншому називають) пактах, можуть певним чином відображатися в умовах дії сучасної конституції, хоча досі незавершеною $€$ дискусія щодо реального статусу Конституції 1710 р. в тому сенсі, наскільки цей документ $€$ конституцією в сучасному розумінні.

Із цього приводу варто зауважити деякі його сутнісні аспекти. За своїм змістом Конституція 1710 р. спрямована на 1) обмеження привласненої понад міру самодержавної влади з метою 2) запобігання безправ'ю, що завдало значної 
шкоди давнім порядкам, правам і вольностям військовим, наклавши тягар на весь народ (преамбула); 3) встановлення зовнішнього курсу й політики (протекторат Шведської Корони, взаємовідносини з Кримською державою тощо); 4) розподіл влади та повноважень між Гетьманом, Генеральною Старшиною, іншими радниками та судом (статті, зокрема 6-10); 5) основи соціальних гарантій (відсутність оподаткування козацьких вдів і сиріт - стаття 11); 6) привілеї місцевого самоврядування (стаття 13); 7) інші основоположні норми податкової, соціальної та політичної спрямованості [1]. Ці ознаки характеризують документ 3 боку укладення в ньому фундаментальних і стабільних основ функціонування суспільства й держави, що, зокрема, виконує й сучасна конституція. Ба більше, забезпечення прав та обмеження державної влади є чи не найголовнішими завданнями конституцій 3 позиції доктрини конституціоналізму. 3 огляду на це, Конституція 1710 р. може бути розглянута як визначний конституційний акт в історії українського права.

Отже, чи можна виокремити певний принцип доброчесності управлінців у Конституції 1710 р. та охарактеризувати його у сучасній інтерпретації? Здебільшого ввесь документ складено з позицій християнських чеснот і будьякі його норми зв'язуються цими доброчесностями. Преамбула Конституції 1710 p. (а отже, і безпосередній текст Пактів) розпочинається з прославлення Бога у Святій Трійці [2, с. 155], що вже можна співвіднести 3 традицією Конституції України, яка, відповідно до преамбули, прийнята з усвідомленням відповідальності перед Богом. Окрім цього, перша стаття Конституції 1710 р. передбачала єдину православну віру східного сповідання та викорінення іновір'я [2, с. 157], що, отже, свідчить про підтримання тих моральних ідей, що несла собою відповідна релігія.

Між тим автор Конституції 1710 р., зазначаючи про православну віру, виходить із логіки трьох богословських чес- нот, першою з яких є віра [2, с. 157]. Як відомо, окрім віри, іншими чеснотами є надія та любов, при цьому остання з них найбільша (I до Kорінтян, 13:13). Принагідно варто зауважити, що дискусія навколо віри як чесноти здійснена ще св. Августином, який у праці «Про град Божий», говорячи про попередні види доброчесності: розсудливість, справедливість, стійкість і поміркованість, указав фактично про їх другорядність, на головне же місце поставивши віру як нову основу доброчесності [3, p. 184]. Тому першим і важливим аспектом Конституції 1710 р. з погляду доброчесності визнані християнські чесноти.

Однак Пакти виділяли й інші важливі достойності, що були необхідні певним представникам влади. Зокрема, стаття шоста передбачала формування загальної ради у Війську Запорізькому. Так, окрім Генеральної Старшини й городових полковників, до складу ради обиралися по одній визначній, розсудливій і заслуженій особі від кожного полку [2, с. 160]. Це свідчить про те, інтерпретуючи сучасною термінологією, що такі особи повинні бути визнаними діячами у своїй царині з відповідним рівнем довіри. Крім того, норма цієі статті передбачає: «Якщц від Ясновельможного гетьмана до загальної ради надійде яка-небудь пропозиція, то всі добропорядно, без своєї чи чужої користі, без душогубних заздрощів та ворогування зобов'язані будуть радити так, щзоб иі поради не призвели до шкоди для честі гетьманської, загальних тягарів Вітчизни, розорення та, не дай Боже, згуби» [1].

Як видно із цієї норми, до радників встановлюються не тільки preconditions, а й умови доброчесності під час своєї діяльності: добропорядність, відсутність конфлікту інтересів, владна синергія. Окрім цього, діяльність ради повинна дбати про гетьманську честь, що є основоположною категорією доброчесності гетьмана. Це можна спостерігати й у преамбулі Пак- 
тів, коли йдеться про обрання Пилипа Орлика як достойного гетьманської честі, так і в статті сьомій, яка регламентує одну з підстав юридичної відповідальності: «ображення гетьманського гонору» $[2$, с. 157, 162].

Окремо варто відзначити особу, яка могла зайняти посаду генерального підскарбія, - людину значну, заслужену, маєтну та добросовісну, а також осіб, що могли бути підскарбіями в полках, - люди значні й багаті (стаття 9) [1]. Отже, встановлюються вимоги 3 погляду доброчесності як здатності до ухвалення справедливих рішень (заслуженість і добросовісність), а також доброчесності як відсутності приватного майнового інтересу чи неправомірної вигоди (маєтність).

Конституція 1710 р. чітко розмежовує публічний і приватний інтерес управлінців, зокрема неможливість отримання власної вигоди від свого становища. Так, стаття десята серед іншого передбачає: «... щцоб панове полковники, сотники, отамани з усіма військовими та посполитими урядниками не наважувалися виконувати панщин та відробітки на своїх приватних господарствах силами козаків та посполитих...», «... остаточно постановляеться, щоб Ясновельможний гетьман жодними, хоч би й найбільшими, подарунками та респектами не спокушався, нікому за хабарі в урядах ні полковничих, ні інших військових чи посполитих посад не давав i насильно в уряд нікого не призначав»; стаття 14 установлює: «... щзоб ні військові чи їхні слуги, ні слуги Ясновельможного гетьмана, переїжджаючи у приватних, а не у військових справах, не вимагали підвод, харчів, напоїв, поклонів та супроводження, бо через ие міста розорюються, а бідний народ знищується» [1]. Отже, з метою запобігання корупції, а також чіткого розділення приватних і публічних справ, Конституція 1710 р. реально встановлює передумови для утвердження фінансової доброчесності.
Конституиійні проекти XIX поч. XX сторіччя. 3 метою відображення тяглості конституційної традиції, зокрема щодо утвердження самостійності України, варто коротко виокремити деякі проекти документів, що можуть бути цікавими 3 погляду конституційного права. Один із політичних документів, запропонованих M. Костомаровим, під назвою «Книга буття Українського народу», або, як ї називає професор М. Томенко, «Світоглядна конституція українських інтелектуалів XIX ст.» [4, с. 41], навряд чи можна назвати конституційним актом для держави, проте деякі його положення мають значення для конституційної думки. Незважаючи на те що М. Костомаровим було запропоновано слов'янський союз (п. 104) [5], надто гостро ставились питання про необхідність здобуття свободи й рівності в Україні. 3 погляду моральних стандартів Книга буття була грунтована на християнських цінностях і вірі, при цьому наполегливо засуджувалися узурпація та самодержавство влади.

Так, у п. 72 М. Костомаров, описуючи історичний український процес, зазначає: "I не любила Україна ні царя, ні пана, а екомпоновала собі козацтво, єсть то ітеє братство»; п. 76 фактично продовжує цю тезу: «... і день ото дня росло, умножалося козацтво і незабаром були на Вкраіні усі козаки, усі вільні $i$ рівні, $i$ не мала б Україна над собою ні изаря, ні пана, опріч Бога єдиного...» [5, с. 256]. Схожі вислови зазначаються й у п. 93, коли йдеться про наслідування християнства на майбутнє. 3 погляду доброчесності представників публічної влади варто сказати, що цей документ установлював передумови для відвернення узурпації влади й установлення чесного християнського урядування.

У Начерках Конституції Республіки Г. Андрузького теж можемо знайти ідею про певний союз слов'янських народів у вигляді штатів, які, у свою чергу, діляться на округи, області й общини [6], проте для правничої 
думки вони (нариси) теж мали вагоме значення. Начерки передбачали досить прогресивні ідеї 3 погляду особистої свободи людини та рівності, де кожен за народженням має право на свободу, майно, рід, життя й рівність перед законом, а також за законними заслугами право на владу та почесті (статті перша і друга Начерків до другого конституційного проекту) [7, с. 418-419]. Між тим, наприклад, в общині на посаду від голови, депутата, старшини чи писаря не могла бути обрана особа, якщо вона поганого поводження, а непристойна поведінка $€$ підставою для відсторонення й відставки кожного члена управи [6], що свідчить про необхідність моральнісної поведінки урядовців.

Відійшов від ідеї об'єднання слов'янських земель, а мав мету створення вільної самостійної України - спілки вільних і самоправних земель - M. Mіхновський і представники Української народної партіі, які в 1905 р. опублікували Основний Закон Самостійної України - Спілки народу українського. У цьому проекті конституції гарантувалося широке коло прав і свобод людини, ї рівність тощо [8]. Окремо потрібно сказати про рівність чоловіків і жінок, серед іншого, допущення їх до виконання офіційних обов'язків (п. 13). Із погляду доброчесного виконання управлінцями своїх обов'язків установлювався відповідний механізм його забезпечення. Так, п. 29 передбачав, що «не потрібен ніякий попередній дозвіл, щзоб пізвати до суду якогось урядовия», п. 70 обмежував право президента на амністію, яку останній не може надати міністрам, хіба що «тільки на жаданне однієї з двох $x a m »-$ ради представників чи сенату (п. 80). Крім того, встановлювався суд присяжних, який був не тільки щодо карних злочинств, а й для переступів пресових і політичних (п. 87) [8]. Отже, бачимо, що представники політичної влади повинні були відповідати перед судом, у якому народ бере безпосередню участь. Крім того, забезпечувався принцип публічності влади: законодатної (п. 38), судової (відкриті засідання та виголошення присуду при відчинених дверях - пункти 85, 86) [8]. Отже, головні принципи морально-етичних стандартів представників публічної влади імпліцитно в цьому проекті конституції виокремити можливо.

Конституиіï УНР, ЗУНР ma інші документи 1917-1920 рр. Конституція Української Народної Республіки, що прийнята 29 квітня 1918 р., проголосила Україну суверенною й самостійною державою (п. 1) [9]. Прямих імперативних правил щодо наявності певних доброчесностей у представників влади, зокрема виконавчої чи судової, в Українській Народній Республіці Конституція не проголошувала, однак вона давала можливості безпосереднього обговорення тих чи інших претендентів представниками народу. Так, по-перше, п'ятий пункт Конституції встановлював: «... не порушуючи єдиної своєї власти, УНР надає своїм землям, волостям і громадам права широкого самоврядування, додержуючи принu̧uпy децеентралізаиії» [9], що фактично означало найбільш наближений рівень представників влади до народу, що формує громадянську довіру, крім того, тут проявляється явний принцип субсидіарності, оскільки широка децентралізація означає не що інше, як вирішення необхідних питань на найбільш низовому рівні.

По-друге, Всенародні Збори, які, згідно $з$ п. 23 Конституції, є верховним органом влади в УНР, надають владу та затверджують Раду Народних Міністрів (виконавчу владу) (пункти 51, 52), а також формують органи судової влади (п. 23) [9]. Очевидно, серед іншого, коли йдеться про судову владу, ii виключне формування законодавчим політичним органом $€$ недосконале, однак, за принципом цієї Конституції, це давало змогу безпосереднім представникам народу призначати тих осіб, які, на їхню думку, змогли б якісно та чесно виконувати свої обов'язки.

Однотипним чином (від органу, в якому зосереджена влада) формува- 
лися Кабінет Міністрів і Генеральний Суд згідно із законом «Про тимчасовий державний устрій України» від 29 квітня 1918 р., виданим Гетьманом усієї Украіни П. Скоропадським. Зокрема, згідно 3 першим пунктом цього документа, влада управління належить виключно гетьману, який призначає Отомана Ради Міністрів і затверджує й скасовує Кабінет (п. 3), а також призначає генеральних суддів (п. 44) [10, с. 84-86]. Отже, щодо особистісних якостей відповідних посадових осіб гетьману належала широка дискреція, однак за проступні на посаді вчинки ОтаманМіністр і Міністри підлягали громадській і карній відповідальності [10, с. 86], що, отже, свідчить про громадянську підзвітність влади.

Значно концентрованим навколо основної проблеми - незалежності Західноукраїнської Народної Республіки, був Тимчасовий Основний Закон про державну самостійність українських земель колишньої Австро-Угорської Монархії, ухвалений 13 листопада 1918 р. Цей документ визначав, зокрема, назву, кордони, державну суверенність, символи тощо [11, с. 96]. Фактичним доповненням до нього був Закон про виділ Української Ради - 9 членів ради та Президент, на яких покладалися обов'язки щодо іменування членів уряду, виконування амністії, призначення начальників верховних державних урядів [11, с. 97], однак, конкретних указівок на певні морально-етичні якості призначуваних представників влади ці документи не надавали.

Нереалізований проект Основного Державного Закону Української Народної Республіки 1920 р., який установлював самостійність і незалежність України, був більш розгорнутим документом щодо формування органів влади, норми якого можуть трактуватися як такі, що основані на принципі доброчесності публічної служби. Так, наприклад, представники законодавчої влади, яка належала Державному Сойму до часу скликання Державної
Ради (артикул 55), згідно з присягою, обіцяли та клялись «Великим Господом перед Святою Його Євангелією, що буду у всьому совісно виконувати обов'язки члена Державного Сойму...» (артикул 60), при цьому в разі невизнання релігійної обітниці було дозволено не складати присягу перед Богом, однак інша частина щодо совісного виконання обов'язків залишалася [12, с. 132-133].

Водночас Головою Української держави, на якого покладається верховна виконавча влада (артикул 106), міг бути громадянин українського походження, православної віри (артикул 107), який має скласти присягу на чесне та сумлінне виконання обов'язків, при цьому мати до всіх справедливість (артикул 119). Принагідно варто зауважити, що ця посада була призначуваною - владою Державної Ради (артикул 119) [12, с. 141-143]. Крім зазначеного, проект конституціі встановлював механізм захисту від непотизму, зокрема в артикулі 127, який передбачав неможливість міністрам, керуючим міністерствами й іншим урядникам бути членами сім'“і Голови Держави [12, с. 144]. Щодо суддів установлювався принцип їх незалежності, а також усність і прилюдність судового процесу [12, с. 146]. Окрім того, проект конституції надавав додаткову можливість на рівні закону визначати необхідні якості представників влади (наприклад, артикули 39, 129, $131,138,140,143)$ [12, с. 130-146], що $€$ достоту важливим для забезпечення владної доброчесності.

Варто згадати про ще один нереалізований проект Конституції Української Народної Республіки 1920 р., запропонований професором Київського університету О. Ейхельманом. Проект передбачав республіканський (проте федеративний) демократичний устрій держави (\$ 1) з владою таких суб'єктів, як установча влада народу та відповідні органи на федеральному рівні: парламент (двопалатний - \$25), державний голова, міністерство, суд, кон- 
трольні органи (\$ 11) [13, с. 17-23]. Сама конституція, згідно зі вступом, була пронизана етичним принципом, за яким державна справа - це вища громадська справа людськості, це справедливе, розумне й моральне державне панування на основі вільного співжиття (частина I, абзаци 2 i 3). Фактично для відстоювання Української держави конституція вимагала розвитку громадської відваги, мужності й політичної мудрості політично-освічених людей, які повинні були глибоко вникнути в чергове питання першорядної ваги та не злякатися дати відповідь на нього по совісті і згідно зі своїм найкращим розумінням (частина V) [13, с. 11-15].

Крім того, проект конституції передбачав не тільки детально розписані інституційні механізми формування й діяльності державної влади, а й основи доброчесності публічних службовців. Зокрема, згідно з присягою членів обох Палат Парламенту, останні повинні совісно виконувати свої обов'язки як щирі оборонці й заступники всіх інтересів і прав УНР (§ 54), при цьому вони у своїй діяльності не могли бути пов'язаними жодними інструкціями, а лиш старанністю допомагати добру Батьківщині відповідно до свого найкращого розуміння ( $\$ 55)$ [13, с. 29-30]. Державним Головою могла бути особа, яка належала до одної з вір християнської релігї ( $\$ 89)$, мала правдою й по совісті служити Батьківщині (§ 112) [13, с. 39-47]. Загалом цей проект містить надзвичайно велику кількість деталей щодо обрання і призначення посадових осіб (що може бути предметом окремого грунтовного дослідження), проте фундаментально текст цієї конституції спирається на високі морально-етичні стандарти представників публічної влади.

3 погляду підтримання континуїтету української конституційної традиції варто звернути увагу на Конституційні Закони Карпатської України від 15 березня 1939 р., які, хоча й не містили норм щодо конкретних механізмів поділу влади та доброчесності їх представників, однак, передбачали в державі республіканізм, шлях обрання президента - Соймом Карпатської України (§ 3, Закон ч. 1), державну мову й символи тощо [14, с. 94-95]. Проте ці документи давали підгрунтя для подальшої співпраці владних представників на основі необхідних морально-етичних засад.

Принцип доброчесності в українській конституційній традиції, зокрема у відповідних конституційних документах, надалі прослідкувати важко, адже до здобуття незалежності України та прийняття спочатку Конституційного договору між Верховною Радою України і Президентом України 1995 р., а надалі Конституції України в 1996 р. дія «совєтських» конституцій не спиралася на реальну історичну традицію конституційного законодавства, позаяк ці документи не були здатні захистити права людини й відстояти суверенітет України та іï самостійність. Тут варто погодитися $з$ думкою професора $M$. Савчина, що «радянський підхід радше слід розглядати як відхід від української конституційної традиції, оскільки радянська концепція права була етатистською за своєю природою $і$ суперечила ідеї обмеження владної сваволі та реального забезпечення гарантій прав людини й основоположних свобод, тяглості української конституцзійної традиціï» [15, с. 85]. Крім того, навряд чи можна говорити про доброчесність влади в контексті нездатності суддів до захисту прав людини, сваволі інших владних напрямів щодо обмеження людини в розвитку іi національної культури, свободи віросповідання тощо. Тому тільки прийнята Конституція України фактично відновила українську конституційну традицію.

Отже, на основі здійсненого дослідження історичних актів конституційного порядку можемо констатувати існування традиції морально-етичних стандартів владних представників в українській конституції. Необхідність цих стандартів проявлялася в різних формах: 1) відповідність християнським чеснотам (e.g. Конституція 
1710 р., проект Основного Державного Закону УНР 1920 р., проект О. Ейхельмана); 2) здатність до ухвалення справедливих i незалежних розсудливих рішень (е.g. проект Основного Державного Закону УНР 1920 р., проект О. Ейхельмана); 3) моральна поведінка (е.g. Начерки Г. Андрузького, проект О. Ейхельмана); 4) майнова доброчесність і відсутність приватного інтересу (е.g. Конституція 1710 р., проект О. Ейхельмана) 5) принципи публічності, відкритості і громадської підзвітності влади (е.g. проект М. Міхновського, Закон про тимчасовий державний устій 1918 р.). Крім того, конституції (проекти) залишали широке поле розсуду під час обрання і призначення посадових осіб, крім того, якщо необхідно, відбір за морально-етичними засадами не заперечувався (е.g. Конституція УНР 1918 р., Закон про тимчасовий державний устій 1918 р.).

Отже, в подальших дослідженнях, а також у практиці формування органів публічної влади на основі чинної Конституції України необхідно враховувати принцип доброчесності, який не був виключно запозичений, але впродовж конституційної української практики вироблений, що проходить шлях еволюціонування й розвитку. Крім того, інтерпретація конституційної доброчесності (зокрема, суддів) у спірних питаннях може бути також почасти здійснена через історичну ретроспективу, якщо це не суперечить новітнім i чинним конституційним принципам, оскільки континуїтет конституційної традиції морально-етичних стандартів влади продовжується.

Ключові слова: морально-етичні стандарти, доброчесність, публічна влада, історія конституції, конституційна традиція.

У статті розглянута конституційна традиція морально-етичних стандартів представників публічної влади. Здійснено аналіз важливих конституиійних актів ( $і$ проектів), які формували конституційний порядок в Українській державі. Виокремлено морально-етичні засади, що були необхідні для публічних службовців під час формування й діяльності владних органів, та охарактеризовано загальне уявлення про тяглість конституційної традицї доброчесності.

В статье рассмотрена конституционная традиция морально-этических стандартов представителей публичной власти. Осуществлен анализ важных конституциионных актов (и проектов), которые формировали конституциинный порядок в Украинском государстве. Выделень морально-этические принципь, которые были необходимы для публичных служащих при формировании и деятельности органов власти, и охарактеризовано общее представление о преемственности конституизионой традиции добродетельности.

The paper deals with the constitutional tradition of moral and ethical standards of public authority. Important constitutional acts (and drafts), which formed the constitutional order in the Ukrainian state, was analyzed. The moral and ethical principles, which were necessary for public servants in the formation and activity of the authorities, were outlined and a general idea of the continuity of the constitutional tradition of moral integrity was described.

\section{Література}

1. Договори $i$ постанови прав $i$ свобод військових між Ясновельможним Його Милості паном Пилипом Орликом, новообраним гетьманом Війська Запорізького, $і$ між генеральними особами, полковниками і тим же Військом Запорізьким з повною згодою з обох cmopir. URL: http://static.rada.gov.ua/ site/const/istoriya/1710.html.

2. Вовк О.Б. Конституція Пилипа Орлика: оригінал та його історія. Архіви України. 2010. № 3-4. С. 145-166.

3. Augustin. The City of God. NPNF1-02. St. Augustin's City of God and Christian 


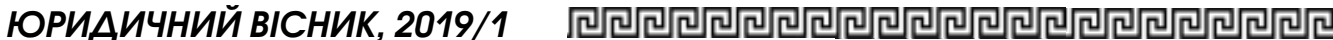

Doctrine. Editor Philip Schaff. New York: The Christian Literature Publishing Co. 1890. 1408 p. URL: http://www.ccel.org/ ccel/schaff / npnf102.html.

4. Томенко М.В. Україна: історія Конституиії : навчальний посібник. Київ : Генеза, 2015. 144 с.

5. Костомаров М. Книга буття Українського народу. Кирило-Мефодї̈вське товариство : у 3 m. Київ : Наук. думка. 1990. T. 1. C. $250-258$

6. Наброски Конституциии Республики, изгятые у Георгия Андрузкого во время обыска в марте 1850 года. URL: http:// nbuviap.gov.ua/asambleya/natonal.php.

7. Андрузький Г. Другий проект Конституиії. Кирило-Мефодї̈ське товариство : у 3 m. Київ : Наук. думка. Т. 2. 1990. $696 \mathrm{c}$.

8. Основний Закон «Самостійної України» спілки народу українського - Проект утворений групою членів Української Народної Партї̈. 1905. URL: http:// nbuviap.gov.ua / asambleya / osnovny_zakon_ samostiynoi_ukrainy_1905.php.

9. Конституція Української Народньої Республіки (Cтатут про державний устрій, права $i$ вільності УНP). URL: https: / / zakon.rada.gov.ua / laws / show / n0002300-18? lang $=u k$.

10. Закон про тимчасовий державний устій України. Конституц̧ійні акти Украї- ни. 1917-1920. Невідомі конституції Украінн. Київ : Філософська і соціологічна думка, 1992. С. 84-86.

11. Тимчасовий Основний Закон про державну самостійність Украӥнських земель бувшої Австро-Угорської Монархї, ухвалений Українською Національною Радою на засіданні 13 падолиста 1918; Закон про виділ Української Ради від 4 січня 1919 року. Конституційні акти України. 1917-1920. Невідомі конституиії України. Київ : Філософська і соціологічна думка, 1992. C. 96-97.

12. Проєкт Правительственної Комісії по виробленню Конституції Українськоі Держави - Основний Держаний Закон Української Народньої Республіки. Конституиійні акти України. 1917-1920. Невідомі конституції України. Київ : Філософська $і$ соиіологічна думка, 1992. С. 126-148.

13. Ейхельман О. Проєкт Конституції - Основних Державних Законів Української Народньої Республіки. Київ-Тернів : Видавниитво С.У.Д. № 2, 1921.96 с.

14. Wтефан A. Августин Волошин Президент Карпатської України. Спомини. Topormo : Toronto free press publications LTD, 1977. 208 c.

15. Савчин М.В. Сучасні тендениії конституціоналізму у контексті глобалізаціі та правового плюралізму : монографія. Ужгород : РІК-У, 2018. $440 \mathrm{c}$. 